\title{
TRADITIONAL VERSUS BLENDED LEARNING METHOD: A COMPARATIVE STUDY ON ITS EFFECTIVENESS IN BUSINESS COMMUNICATION COURSE
}

\author{
Fahad AlShahrani ${ }^{1}$ and Gilbert M. Talaue ${ }^{2}$ \\ ${ }^{1}$ Assistant Professor of English Language and Director of e- Learning Center, Royal \\ Commission of Jubail, Jubail Industrial City, Kingdom of Saudi Arabia \\ ${ }^{2}$ Assistant Professor of Business Administration, Jubail University College, Jubail \\ Industrial City, Kingdom of Saudi Arabia
}

\begin{abstract}
This article presents a descriptive comparative study on two methods of teaching, the traditional and blended learning pedagogical approach in a Business Communication course. Forty-four (44) students from the two controlled groups were enrolled in the course for the first semester of school year 2017-2018 participated in the study. The findings indicated that respondents' performance in ENGL118 (English Composition) had an effect on their performance in BUS261(Business Communication) and there was a significant positive relationship between year level and final grade in BUS261. Therefore, it was concluded that the year level and grade in ENGL118 have correlationson student'sperformance in BUS261. The results of the assessments of the two groups were compared and indicated a significant difference in the results which was influenced by respondents' year level and mode of conducting assessments. It is further concluded, that if the characteristics of both groups were the same, blended would have been more effective than the traditional method.This study recommends adopting the blended pedagogical approach not only in BUS261 course but also to other courses as applicable.
\end{abstract}

\section{KEYWORDS}

Flipped Class, Blended Learning, BlackBoard, Business Communication, Teaching Pedagogy.

\section{INTRODUCTION}

In the traditional method of teaching, the teacher is typically the central focus of a lesson and the primary disseminator of information during the class period. The teacher responds to questions while students defer directly to the teacher for guidance and feedback. In a classroom with a traditional method of instruction, individual lessons may be focused on an explanation of content utilizing a lecture-style. Student engagement in the traditional method may be limited to activities in which students work independently or in small groups on an application task designed by the teacher. Class discussions are typically centered on the teacher, who controls the flow of the conversation [23].

DOI : 10.5121/ijait.2018.8601 
A flipped classroom is an instructional strategy and a type of blended learning that reverses the traditional learning environment by delivering instructional content, often online, outside of the classroom. It moves activities, including those that may have traditionally been considered homework, into the classroom. In a flipped classroom, students watch online lectures, collaborate in online discussions, or carry out research at home while engaging in concepts in the classroom with the guidance of a mentor.Typically, this pattern of teaching also involves giving students the task of reading from a textbook or practicing a concept by working on a problem set, for example, outside school [29]. In flipped learning environment the classroom is where students reinforce their knowledge and present their learning outcomes. Flipping the learning process is considered to be one of the best ways to introduce blended learning in any educational institution.

With the popularity of digital instructional resources and access to high-speed bandwidth and devices, many universities, colleges, and schools are experimenting with ways of combining online and regular classroom instruction to support teaching and improve students' learning experiences. This blending of online and face-to-face instruction is expected to be standard practice in many classrooms in the future. Blended learning methods are being adopted for a variety of purposes. Some are extending instructional time at lower costs by using online programs to deliver instruction during an extra block of class time while paraprofessionals monitor the classroom or lab. Teachers are using blended methods to add variety to their instruction and to free them to spend more time working with individual students. Schools are also using the adaptive and self-paced nature of some online systems to renegade students, particularly those with the greatest academic needs, by enabling them to learn at their own pace and appropriate level of challenge [28].

Blended learning is a format rapidly spreading in education worldwide. The idea of it looks attractive. It allows the compromise of integrating technologies into the teaching process, following the tendency of using them in education as in any other area of human activity [20]. A lot of research has been done on the favorable effect of the use of new technologies on a learning process in terms of facilitation and enhancement [2]. Attention has also been given to some constraints and limitations of the use of technology in education [9].

Even with a lot of findings proving the effectiveness of technology in some sectors, still,the question remains: Does the use of technology in education or the so-called "blended learning methods" really more effective than "traditional ways" of teaching?

This paper is an attempt to assess the effectiveness of "traditional" and "blended learning" pedagogical approach in Business Communication Course at Jubail University College - Male Branch during the first semester of the school year 2017-2018.

Jubail University College is an affiliate of the Royal Commission for Jubail \& Yanbu. It was established in 2006 to achieve the objectives of the Royal Commission, in developing human resources and to provide the Saudi manpower with high education and training so that they can

properly manage the Kingdoms' growing economy in its various sectors. Jubail University Colleges' mission is to achieve the following objectives: (a) to contribute to the stability of the 
local community in Jubail Industrial City and to attract qualified Saudi nationals to work in and manage the city projects; (b) to provide well-trained and qualified Saudi manpower to meet the requirements of industrial development projects and investment in Jubail Industrial City; and (c)

to achieve a distinctive level of performance in the applied academic field to prepare professionals who can keep pace with and utilize global technological developments [15].

The Business Communication course is one of the general courses in Jubail University College. It means that all students regardless of their major or specialization should take this course. As per approved course specification, Business Communication is described as "Principles, techniques, and skills needed to conduct scientific, technical, or business writing. Forms and styles of communication in and among business organizations, business letters, and library research projects and use of business periodicals. Preparation and presentation of oral reports will be covered. Instruction in the writing of reports, letters, and other exercises applicable to a wide range of disciplines and careers. Emphasis on clarity, conciseness, and accuracy of expression. Research techniques, information design, effective use of graphics. Eventually, students will produce a properly formatted report, complete with an outline and supporting graphics aids", with 3 credit hours, and 45 contact hours [15].

Two controlled groups were investigated in this study, section 101 and section 103 . Section 101 applied the traditional pedagogical approach while section 103 applied the blended learning approach (flipped learning).

Traditional classroom teaching focuses on a number of elements where learning is conducted in a synchronous environment. The instructor and the students must be in the same place at the same time in order to derive motivation and instruction from the teacher as well as from the other students. According to Chickering \& Gamson (1987), as cited by Simon, et. al [27], this has been a customary teaching method because "sharing one's own ideas and responding to others' reactions improves thinking and deepens understanding" In this environment, educators have the opportunity to identify the needs of students and motivate them on an individual basis.

Since blended learning is an emerging field there are currently many different conceptualizations of what it means to "do" blended learning. The definition adopted for this research report, following Staker and Horn [28], has the following components: it involves teaching and learning within a formal education program; students learn at least in part through online delivery of content and instruction; students have some level of control over time, place, path and/or pace of instruction; and part or all of the instruction is delivered away from home in a supervised, brickand-mortar location.

\subsection{Research questions}

This study aims to assess the effectiveness of both "traditional" and "blended learning" pedagogical approach in Business Communication Course during the first semester of the school year 2017-2018, specifically, it aims to answer the following questions: 
What is the demographic profile of the respondents in terms of the following variables:

a) major;

b) byear level;

c) grades in ENGL118 (English Composition)

Is there a correlation of the above-mentioned variables to the performance of respondents in the Business Communication course?

Is there a significant difference in the performance of students in two controlled groups in terms of the following variables:
a) assignments;
b) quiz 1 ;
c) quiz 2 ;
d) midterm exam;
e) final exam.

What are the perceptions of respondents with regards to two teaching methods?

What are the factors that affect the effectiveness or ineffectiveness of the two teaching methods?

\subsection{Hypotheses}

Ho1. There is no correlation between major, year level, and grades in ENGL118 (English Composition) to the performance of respondents in BUS261 (Business Communication) course.

Ho2. There no significant difference in the performance of students in two controlled groups terms on the following variables: assignments; quiz 1; quiz 2; midterm exam; and a final exam.

\section{RELATED LiteratURE REVIEWED}

Various findings from studies related to this paper were reviewed by the researchers that enabled them to gain conceptual background. These findings are presented successively:

Aslam [3] found out that students who were taught with the blended learning model had better scores than those who attended traditional instruction. The test results are in agreement with Omiola [22], who also argued that participants in the treatment group or blended environments have the potential to strengthen the core of teaching and learning, to provide the student with enough opportunities to learn in a fun way. This is a very important finding and the results also show that students were not only enjoying the blended environments but it also leads to critical thinking. The classroom discussions and activities encouraged in the blended classes encouraged

students to think critically and their higher order thinking questions reflected the interest developed towards the subject. Overall, the findings reinforce the view that a blended learning environment promotes student-centered learning and critical thinking by giving the opportunity 
and providing a conducive environment where students take more responsibility for their learning and increase the involvement and participation necessary for such learning.

Based on the results, blended learning may be used as an effective way to deliver good quality instruction as it gives educationalists and students a technology-based advantage to student achievement and richer and more rewarding learning experiences in a fun way.

According to Nazarenko [20], there is quite a high percentage of non-favorable opinions of the students of this format of study involving extensive use of technologies. That seems to be

unexpected of young people today, who are real "digital natives", "Generation Z", etc., not imagining their life without smart electronic devices and gadgets. Nazarenko adds that though they can be absolutely absorbed in some entertaining activities (playing computer games, watching streamline videos and films and so on), quite a few of them would be rather resistant to learning with technologies. Within this category, there are students who will be unwilling to deal with textual materials (reading and writing in the virtual space) but will be responsive to analyzing and summarizing visual learning materials (videos and films). Visual perception is characteristic of multimedia users, young people of today who were brought up on modern technologies.

Khan [16] concluded that that Blended learning provides flexibility in learning for both students and teachers. Integration of the virtual and physical landscapes enables both instructors and students to become learners, but this is most effective when there is institutional support through the provision of professional learning and the opportunity for redesigning courses for the most appropriate blend [6]. Heinze and Procter [14] definition of blended learning as follows: "Blended learning is learning that is facilitated by the effective combination of different modes of delivery, models of teaching and styles of learning, and is based on transparent communication amongst all parties involved with a course ".

Al-Azawie [4] found out that blended learning combines the advantages of traditional and online learning. It is widely applied to support face-to-face learning as well as responding to user needs. Investigating learner satisfaction and intention to use e-learning alongside physical classrooms can predict whether learners will continue using this technology or not.

Crawford, R., Jenkins, L. [7]indicated that the development and implementation of blended learning and team teaching strategies had positive outcomes on both the learning and teaching in this pre-service methods unit. Students were also able to draw links between the pedagogical approach taken in the unit to their own developing teacher practice. While this was a learning intention, the connections the pre-service teachers made developed quite organically as a result of the combined methods used by the research teachers. Exploring alternative structures, strategies and approaches to teaching are critical in modeling good practice, which is particularly pertinent

in the context of pre-service teacher education. This is also important in contemporary education more generally, to ensure that the new generation of teachers is ready for the requirements of a flexible and rapidly changing teaching and learning environment. While students indicated that they were more confident in utilizing team teaching strategies, rather than blended learning in the 
classroom, there is a clear indication of the valued potential and the willingness to develop these innovative skills and approaches.

The reviewed studies provided the researchers with a rich background on the effectiveness of traditional and blended learning methods. This enabled the researchers to come-up with a conceptual background of the present study and identify the variables in the investigation. Figure 1 shows the paradigm of the study.

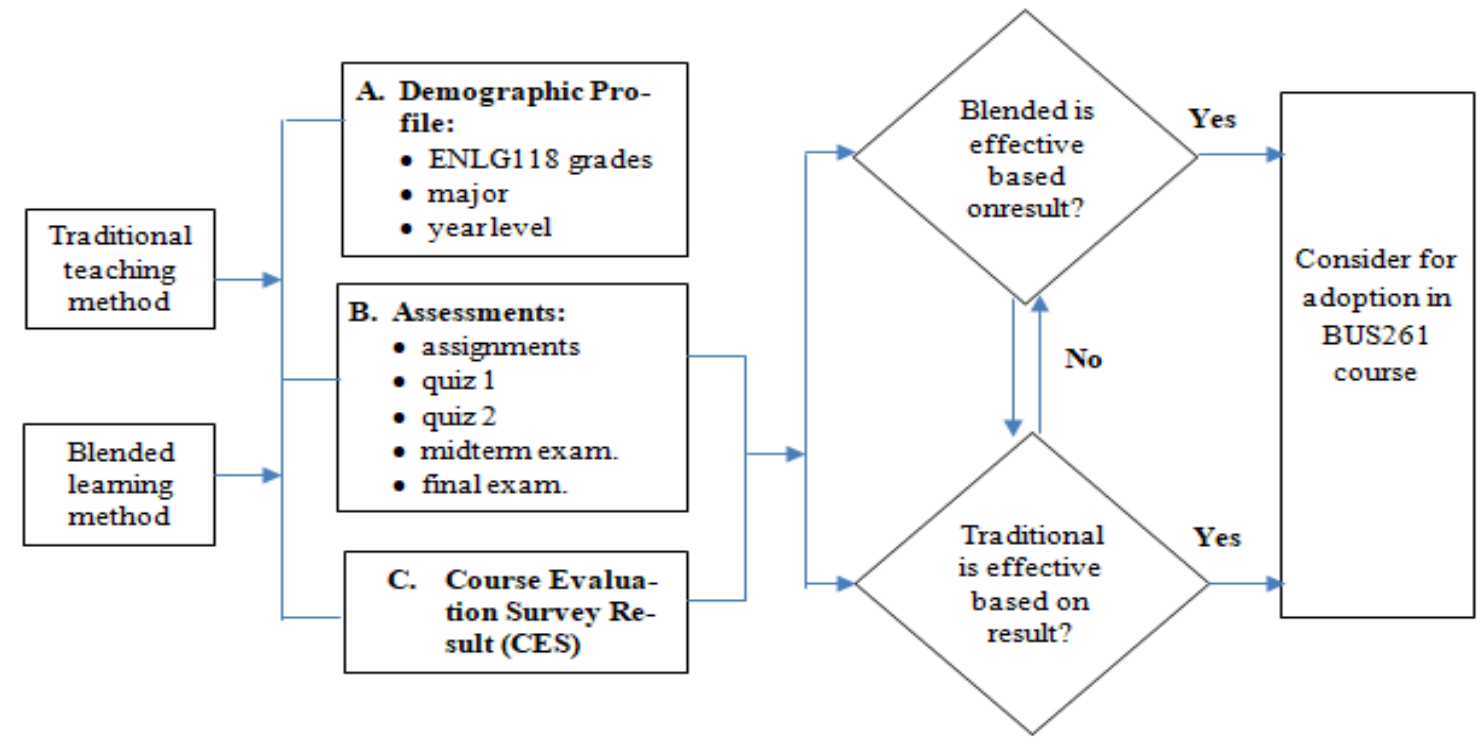

Figure 1: Paradigm of the Study

\section{Methodology}

The study used the descriptive method of research in assessing the effectiveness of "traditional" and "blended learning" pedagogical approaches in a Business Communication course.

\subsection{Sources of Data}

To determine the appropriate sample size, Cochran's formula was used [8]. Formula is written as:

$$
n_{0}=\frac{Z^{2} p q}{e^{2}}
$$

where:

$$
\begin{aligned}
& \mathrm{e}=\text { desired level of precision } \\
& \mathrm{p}=\text { estimated proportion of the population } \\
& \mathrm{q}=1-\mathrm{p} . \\
& \mathrm{Z}=\mathrm{z} \text {-value in } \mathrm{Z} \text { table }
\end{aligned}
$$


Since population size is known, 49 students, Cochran's formula was modified as follows:

$$
n=\frac{n_{0}}{1+\frac{\left(n_{0}-1\right)}{N}}
$$

where:

$$
\begin{aligned}
& \mathrm{n}_{0}=\text { Cochran's sample size population (384) } \\
& \mathrm{N}=\text { total population size } \\
& \mathrm{n}=\text { adjusted sample size }
\end{aligned}
$$

thus,

$$
\begin{aligned}
\mathrm{n} & =384 /(1+(383 / 49)) \\
& =43.56 \text { or } \mathbf{4 4}
\end{aligned}
$$

The respondents of the study are the forty-four (44) students enrolled in BUS261 (Business Communication) course during the first semester of the school year 2017-2018. In section 101 with 26 students, traditional method was applied in their class, while section 103 with 23 students, utilized the blended-learning approach. Using the Cochran's formula and 0.05 error of margin, the researchers computed that forty-four (44) respondents were appropriate.

Table 1. Distribution of Respondents

\begin{tabular}{cccc}
\hline Section & $\begin{array}{c}\text { Number of } \\
\text { Students }\end{array}$ & $\begin{array}{c}\text { No. of } \\
\text { Respondents }\end{array}$ & Percentage \\
\hline 101 & 26 & 22 & $84 \%$ \\
103 & 23 & 22 & $96 \%$ \\
Total & 49 & 44 & $\mathbf{9 0 \%}$
\end{tabular}

\section{ReSUlt AnAlysis ANd Discussions}

\subsection{The demographic profile of the respondents in terms of: major, year level, grade in BUS261, and grade in ENGL118}

In order to generate the demographic profile of respondents, in terms of the aforementioned variables, the researchers coordinated with the college registrar. The college registrar generated the needed data from the Student Information System (SIS). Thus, the researchers profiled the variables accordingly. Succeeding tables presented the profiles of the respondents. 
International Journal of Advanced Information Technology (IJAIT) Vol. 8, No.6, December 2018

Table 2. Profile of Respondents in terms of Year Level

\begin{tabular}{ccc}
\hline Year Level & $\begin{array}{c}\text { No. of Stu- } \\
\text { dents }\end{array}$ & Percentage \\
\hline $1^{\text {st }}$ & 4 & $9 \%$ \\
$2^{\text {nd }}$ & 2 & $5 \%$ \\
$3^{\text {rd }}$ & 2 & $5 \%$ \\
$4^{\text {th }}$ & 6 & $14 \%$ \\
$5^{\text {th }}$ & 9 & $20 \%$ \\
$6^{\text {th }}$ & 5 & $11 \%$ \\
$7^{\text {th }}$ & 16 & $36 \%$ \\
Total $^{\text {th }}$ & $\mathbf{4 4}$ & $\mathbf{1 0 0 \%}$
\end{tabular}

Table 2 shows that $16(36 \%)$ of respondents are already on their 7 th level or senior year, it means these students are already on their last semester in the college and almost done with all the academic courses. These $16(36 \%)$ comprises of the following students as shown in Table 3: BUS with 1, CE with 6, CS with 2, ME with 7, and MIS with 2 students on their 7th level.

Table 3. Profile of Respondents in terms of Major and Year Level

\begin{tabular}{lcccc}
\hline Major/Specialization & $\begin{array}{c}\text { Year } \\
\text { Level }\end{array}$ & $\begin{array}{c}\text { No. of Stu- } \\
\text { dents }\end{array}$ & Percentage & $\begin{array}{c}\text { Percentage per } \\
\text { Specialization }\end{array}$ \\
\hline ACCT (Accounting) & 1st & 4 & $9 \%$ & $11 \%$ \\
\hline BUS (Business & 4 th & 1 & $2 \%$ & $11 \%$ \\
Administration) & 5 th & 1 & $2 \%$ & \\
& 6 th & 2 & $5 \%$ & \\
\hline CE (Civil Engineering) & 7 th & 1 & $2 \%$ & $14 \%$ \\
\hline CS (Computer Science) & 2nd & 6 & $14 \%$ & $11 \%$ \\
& 4 th & 1 & $2 \%$ & \\
& 5 th & 1 & $2 \%$ & $34 \%$ \\
ME (Mechanical & 7 th & 2 & $5 \%$ & \\
Engineering) & $3 \mathrm{rd}$ & 1 & $2 \%$ & \\
& 4 th & 2 & $5 \%$ & $18 \%$ \\
& 5 th & 4 & $2 \%$ & \\
\hline MIS (Management In- & 6th & 1 & $16 \%$ & \\
formation System) & 7th & 7 & $2 \%$ & \\
& 4 th & 1 & $5 \%$ & \\
\hline TOT AL & 5 th & 3 & $7 \%$ & \\
\hline
\end{tabular}


International Journal of Advanced Information Technology (IJAIT) Vol. 8, No.6, December 2018

Table 4. Profile of Respondents in terms of Grades in ENGL118 and BUS261 per Specialization

\begin{tabular}{|c|c|c|c|c|c|c|c|c|c|c|c|c|}
\hline \multicolumn{10}{|c|}{ No. of Students per Grade in each Specialization } \\
\hline & \multicolumn{1}{|c|}{ ACCT } & \multicolumn{2}{c|}{ BUS } & \multicolumn{2}{c|}{ CE } & \multicolumn{2}{c|}{ CS } & \multicolumn{2}{c|}{ ME } & \multicolumn{2}{c|}{ MIS } \\
\hline Grade & ENGL & BUS & ENGL & BUS & ENGL & BUS & ENGL & BUS & ENGL & BUS & ENGL & BUS \\
& 118 & 261 & 118 & 261 & 118 & 261 & 118 & 261 & 118 & 261 & 118 & 261 \\
\hline $\mathrm{A}+$ & 0 & 0 & 0 & 0 & 0 & 0 & 0 & 0 & 1 & 1 & 0 & 0 \\
\hline $\mathrm{A}$ & 0 & 0 & 0 & 0 & 0 & 0 & 0 & 0 & 2 & 0 & 0 & 1 \\
\hline $\mathrm{B}+$ & 0 & 0 & 1 & 1 & 1 & 0 & 0 & 1 & 2 & 6 & 1 & 1 \\
\hline $\mathrm{B}$ & 0 & 0 & 0 & 2 & 2 & 0 & 0 & 1 & 4 & 1 & 0 & 1 \\
\hline $\mathrm{C}+$ & 0 & 1 & 1 & 1 & 2 & 4 & 1 & 1 & 4 & 3 & 2 & 3 \\
\hline $\mathrm{C}$ & 0 & 1 & 0 & 0 & 1 & 0 & 2 & 1 & 2 & 2 & 3 & 2 \\
\hline $\mathrm{D}+$ & 0 & 1 & 1 & 1 & 0 & 2 & 1 & 0 & 0 & 1 & 2 & 0 \\
\hline $\mathrm{D}$ & 0 & 2 & 2 & 0 & 0 & 0 & 1 & 1 & 0 & 1 & 0 & 0 \\
\hline $\mathrm{F}$ & 0 & 0 & 0 & 0 & 0 & 0 & 0 & 0 & 0 & 0 & 0 & 0 \\
\hline
\end{tabular}

This profiling of variables led the researchers to find the correlation between the major, year level, and ENGL118 grades to the performance of respondents in BUS261.

\subsection{Correlation of the major, year level, and ENGL118 grades to the performance of respondents in BUS261}

Table 5. Correlation of Final Grades in ENGL118 and BUS261

\begin{tabular}{llll}
\hline & & $\begin{array}{l}\text { Final Grade } \\
\text { ENGL118 }\end{array}$ & $\begin{array}{l}\text { Final Grade } \\
\text { BUS261 }\end{array}$ \\
\hline Final Grade & Pearson Correlation & 1 & $0.429^{* *}$ \\
ENGL118 & Sig. (2-tailed) & & 0.004 \\
& $\mathrm{~N}$ & 44 & 44 \\
\hline Final Grade & Pearson Correlation & $.429^{* *}$ & 1 \\
BUS261 & Sig. (2-tailed) & 0.004 & \\
& $\mathrm{~N}$ & 44 & 44 \\
\hline ** Correlation is significant at the 0.01 level (2-tailed). &
\end{tabular}

ENGL118 is the prerequisite course of BUS261, except for Accounting degree wherein there is no prerequisite course for BUS261 in their degree plan. Table 5 shows the correlation between ENGL118 and BUS261.

There is a significant positive relationship between ENGL118 grade and BUS261 grade, $\mathrm{r}(44)=$ $0.429, \mathrm{p}=0.004$. Therefore, respondents' performance in ENGL118 has effect on their performance in BUS261 
Table 6. Correlation of Year Level and Final Grade in BUS261

\begin{tabular}{llll}
\hline & Year Level & $\begin{array}{l}\text { Final Grade } \\
\text { BUS261 }\end{array}$ \\
\hline Year Level & Pearson Correlation & 1 & $0.436^{* *}$ \\
& Sig. (2-tailed) & & 0.003 \\
& $\mathrm{~N}$ & 44 & 44 \\
\hline Final Grade & Pearson Correlation & $0.436^{* *}$ & 1 \\
BUS261 & Sig. (2-tailed) & 0.003 & \\
& $\mathrm{~N}$ & 44 & 44 \\
\hline${ }^{* *}$ Correlation is significant at the 0.01 level (2-tailed).
\end{tabular}

Table 6 shows the correlation of year level and final grade in BUS261. There is a significant positive relationship between year level and final grade in BUS261, $r(44)=0.436, p=0.003$. Thus, it is safe to say that the higher the year level of respondent, the greater the possibility of earning a higher possible grade in BUS261.

Table 7. Correlation of Major and Final Grade in BUS261

\begin{tabular}{llll}
\hline & Major & $\begin{array}{l}\text { Final Grade } \\
\text { BUS261 }\end{array}$ \\
\hline Major & Pearson Correlation & 1 & $.419^{* *}$ \\
& Sig. (2-tailed) & & 0.005 \\
& $\mathrm{~N}$ & 44 & 44 \\
\hline Final Grade & Pearson Correlation & $.419^{* *}$ & 1 \\
BUS 261 & Sig. (2-tailed) & .005 & \\
& $\mathrm{~N}$ & 44 & 44 \\
\hline ** Correlation is significant at the 0.01 level (2-tailed). &
\end{tabular}

Table 7 shows the correlation of major and final grade in BUS261. There is a significant positive relationship between Major and Final Grade in BUS261, r(44) $=0.419, \mathrm{p}=0.005$, therefore there is a statistically significant correlation.

To further prove the correlation between Final Grade in BUS 261 with the following variables: ENGL118, Major, and Year Level, linear regression analysis was performed. Table 8to 10 shows the results.

Table 8: Model Summary

\begin{tabular}{ccccc}
\hline Model & $\mathrm{R}$ & R Square & $\begin{array}{c}\text { Adjusted R } \\
\text { Square }\end{array}$ & $\begin{array}{c}\text { Std. Error of the } \\
\text { Estimate }\end{array}$ \\
\hline 1 & $.498^{\mathrm{a}}$ & .248 & .240 & 7.70585 \\
\hline
\end{tabular}

a. Predictors: (Constant), Final Grade ENGL118, Major, Year Level 
Table 8 provides the $\mathrm{R}$ and $\mathrm{R} 2$ values. The $\mathrm{R}$ value represents the simple correlation and is 0.4.98, which indicates a high degree of correlation. The $\mathrm{R} 2$ value indicates how much of the

total variation in the dependent variable, Final Grade in BUS261, can be explained by the independent variables: Final Grade ENGL118, Major, and Year Level In this case, 24.8\% is very low.Therefore, it can be concluded that there is statistically significant correlation, but the independent variables cannot be the sole predictors of student's performance in BUS261.

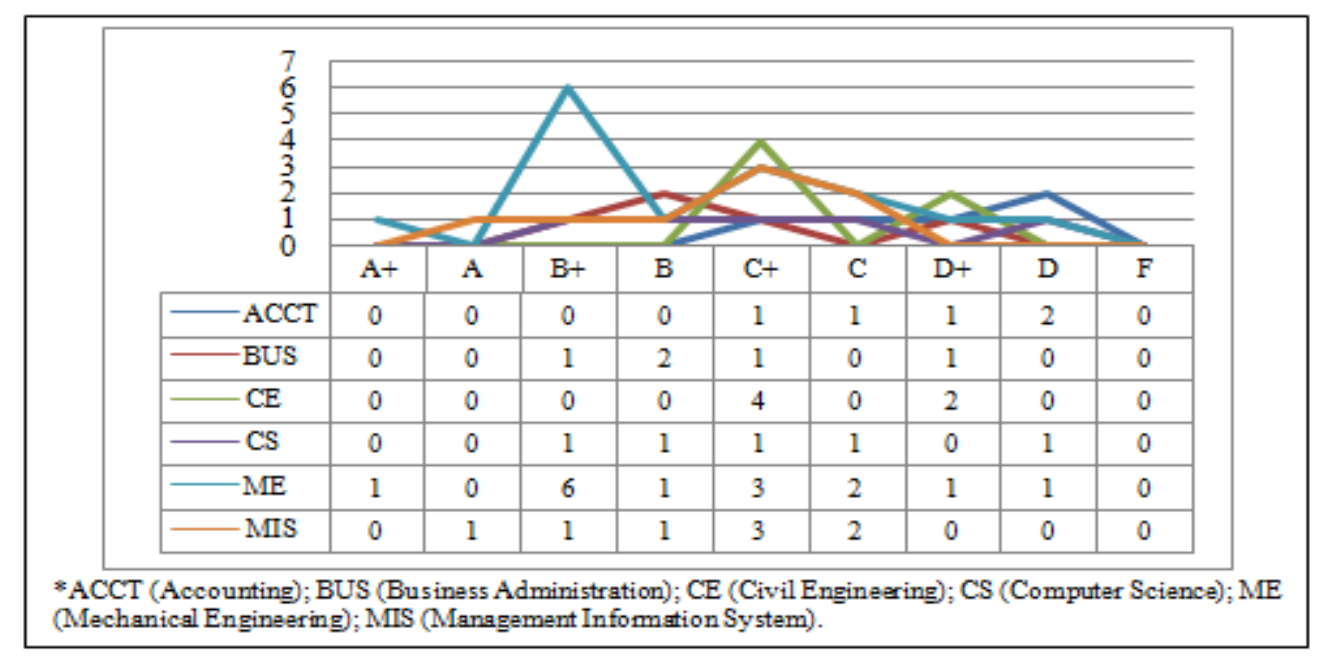

Figure 2. Distribution of BUS261 Grades per Specialization

Figure 2 shows that ME peaked in the graph, showing that this group of students earned the highest grades. One of the aspects that may influence their performance is the majority of $\mathrm{ME}$ students are already in 7thyear level. Please note that in Table 6 shows the correlation of year level and final grade in BUS261, wherein $\mathrm{r}(44)=0.436$, which can be concluded as moderate uphill (positive) linear relationship, therefore there is a statistically significant correlation. It can be concluded that the higher the year level of respondents, the greater the possibility of earning a higher possible grade in BUS261.

\subsection{The difference in the performance of students in two controlled groups in terms of assignments, quiz 1, quiz 2, midterm exam, and final exam}

The assessments given to the two controlled groups are all the same, but how it was administered is different. Section 101's assignments were done using the traditional "paper and pencil", wherein they did and submit their assignments in handwritten or printed format, while section 103 did and submit their assignment online using the "BlackboardLearn". BlackboardLearn is a virtual learning environment and course management system developed by Blackboard Inc. It is Web-based server software which features course management, customizable open architecture, and scalable design that allows integration with student information systems and authentication protocols. It may be installed on local servers or hosted by Blackboard ASP Solutions. Its main purposes are to add online elements to courses traditionally delivered face-to-face and to develop completely online courses with few or no face-to-face meetings[5]. 
International Journal of Advanced Information Technology (IJAIT) Vol. 8, No.6, December 2018

Quiz 1, quiz 2, midterm exam, and final exam were administered face-to-face. Table 9 shows the statistics of these assessments.

Table 9. Group Statistics for Assessments

\begin{tabular}{llllll}
\hline & Section & N & Mean & $\begin{array}{l}\text { Std. Devia- } \\
\text { tion }\end{array}$ & $\begin{array}{l}\text { Std. Error } \\
\text { Mean }\end{array}$ \\
\hline Assignments & 101 & 22 & 7.5354 & 1.46199 & 0.11561 \\
& 103 & 22 & 6.1677 & 1.14705 & 0.10060 \\
\hline Quiz 1 & 101 & 22 & 7.7173 & .90510 & 0.07157 \\
& 103 & 22 & 7.2227 & 1.56465 & 0.13723 \\
\hline Quiz 2 & 101 & 22 & 7.5197 & 1.76638 & 0.13968 \\
& 103 & 22 & 7.4653 & 1.47384 & 0.12926 \\
\hline Midterm Exam & 101 & 22 & 15.2805 & 2.63643 & 0.20848 \\
& 103 & 22 & 13.5216 & 3.09583 & 0.27152 \\
\hline Final Exam & 101 & 22 & 32.9848 & 3.28533 & 0.25979 \\
& 103 & 22 & 30.3286 & 4.65454 & 0.40823 \\
\hline
\end{tabular}

Table 8 shows the results suggest that section 101 outperformed section 103 in the belowmentioned assessment due to the following conditions: section 103 applied the blended learning method, in which they did assignments online using Blackboard.

Table 10. Independent Samples Test for Assessments

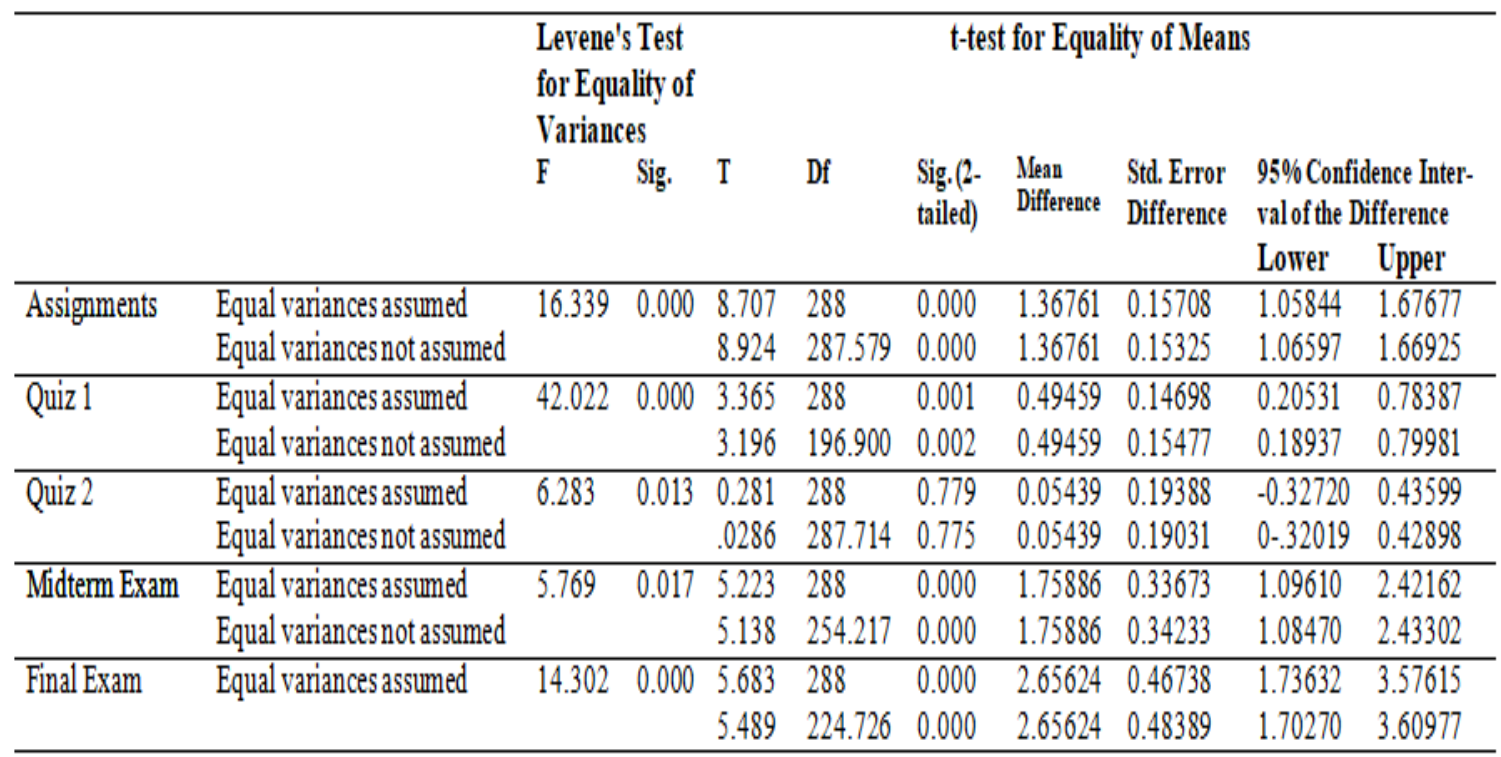

Table 10 shows the independent-samples t-test comparing the results of assignments, quiz 1, quiz 2, midterm exam and final exam of sections 101 and 103. The results are as follows: 
- There was a significant difference in assignments scores of section $101 \quad(\mathrm{M}=7.54$, $\mathrm{SD}=1.46)$ and section $103(\mathrm{M}=6.17, \mathrm{SD}=1.15)$ conditions; $\mathrm{t}(288)=8.71, \mathrm{p}<0.001$;

- There was a significant difference in quiz 1 scores of section $101(\mathrm{M}=7.71, \mathrm{SD}=0.90)$ and section $103(\mathrm{M}=7.22, \mathrm{SD}=1.56)$ conditions; $\mathrm{t}(288)=3.365, \mathrm{p}=0.001$;

- There is no significant difference in quiz 2 scores of section $101(\mathrm{M}=7.52, \mathrm{SD}=1.77)$ and section $103(\mathrm{M}=7.47, \mathrm{SD}=1.47)$ conditions; $\mathrm{t}(288)=0.281, \mathrm{p}=0.78 ; 1$

- There was a significant difference in midterm exam scores of section $101(\mathrm{M}=15.28$, $\mathrm{SD}=2.64)$ and section $103(\mathrm{M}=13.52, \mathrm{SD}=3.10)$ conditions; $\mathrm{t}(288)=5.22, \mathrm{p}<0.001$;

- There was a significant difference in final exam scores of section $101 \quad(M=32.98$, $\mathrm{SD}=3.28)$ and section $103(\mathrm{M}=30.33, \mathrm{SD}=4.65)$ conditions; $\mathrm{t}(288)=5.68, \mathrm{p}<0.001$.

Students are given only 20 minutes for each assignment. After 20 minutes the Blackboard will lock, not allowing the students to continue answering their assignments. Unlike in section 101 that applied the traditional method, whereas the assignments are done using the 'pen and paper' and were given a longer time. This method affects the result in assignments, that's why section 101 got higher marks than section 103, and there are higher year-level students in section 101 so there is a greater possibility that these students performed well, based on the finding in research question 2.

\subsection{The perceptions of students with regards to two teaching methods}

Based on the Course Evaluation Survey (CES), which is being conducted every end of the semester consisted of 26 specific question divided into five sections in which students evaluate the faculty performance at the start of the course, during the course, after the course, and overall rating with the last section (3 questions) giving opportunity for comments. The responses in 23 questions were measured on a five-point Likert scale, ranging from 1 (strongly disagree) to 5 (strongly agree). The survey questions were re-grouped under five factors that predicted to significantly influence the rating of student evaluation of teaching effectiveness, namely: the instructor's personality traits, his/her behavior in marking and grading, his/her knowledge and teaching ability, the course attributes, and the course learning outcomes. The survey is administered electronically where all enrolled full-time undergraduate students were mandatorily required to complete the survey in a pre-designated computer lab [31].

Out of the 26 questions on CES, the researchers selected only the following questions that are directly related to delivering the course, particularly the use of technology to support learning. This question item is (Q12) "in this course effective use was made of technology to support my learning".

Table 11. Group Statistics for Q11 and Q12 of CES

\begin{tabular}{llllll}
\hline & Section & N & Mean & $\begin{array}{l}\text { Std. Devi- } \\
\text { ation }\end{array}$ & $\begin{array}{l}\text { Std. Error } \\
\text { Mean }\end{array}$ \\
\hline Q12 & 101 & 22 & 3.46 & 1.73 & 0.522 \\
& 103 & 22 & 4.18 & 1.73 & 0.522 \\
\hline
\end{tabular}


International Journal of Advanced Information Technology (IJAIT) Vol. 8, No.6, December 2018

Table 12. Independent Samples Test for Q11 and Q12 of CES

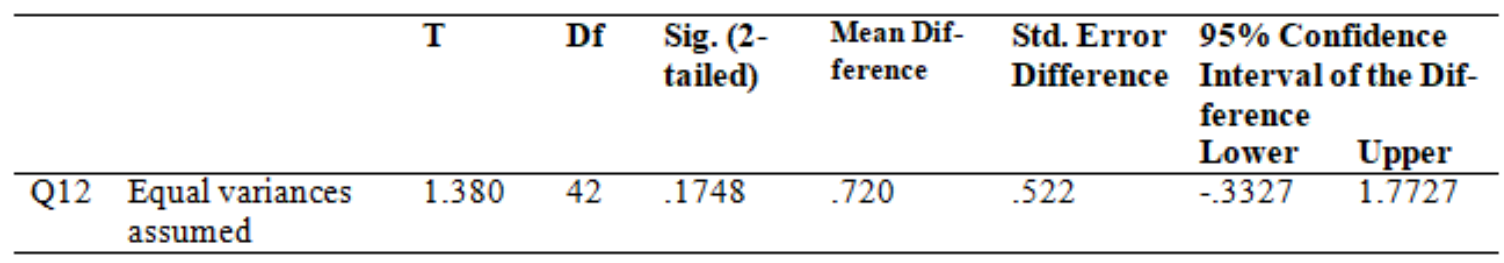

Independent-samples t-test was conducted to compare respondents' rating on Q12. Tables 11 and 12 shows that there was no significant difference in Q12's rating for section $101(\mathrm{M}=3.46$, $\mathrm{SD}=1.73)$ and section $103(\mathrm{M}=4.18, \mathrm{SD}=1.73)$ conditions; $\mathrm{t}(42)=1.380, \mathrm{p}=0.1758$. This result suggests a neutral viewpoint of respondents in using technology for learning.

\subsection{Factors that affect the result of effectiveness or ineffectiveness of two teaching methods}

The researchers also selected the following questions in the CES that directly related to assessing the effectiveness of teaching methods and overall course evaluation average. These are: (Q18) "grading of my tests and assignments in this course was fair and reasonable"; overall course evaluation average; percentage of satisfaction for the instructor; and percentage of satisfaction for materials and resources.

The following Table 13 and Table 14 indicates the descriptive statistics and results of independent-samples t-test which compare respondents' rating and related question items in CES. The analysis as follows:

- There is no significant difference in respondents' rating in Q18 of section $101(\mathrm{M}=3.25$, $\mathrm{SD}=0.76)$ and section $103(\mathrm{M}=3.64, \mathrm{SD}=0.76)$ conditions; $\mathrm{t}(42)=1.702, \mathrm{p}=0.096$;

- There is no a significant difference in respondents' rating in 'satisfaction for instructor' of section $101(\mathrm{M}=3.6, \mathrm{SD}=1.42)$ and section $103(\mathrm{M}=4.03, \mathrm{SD}=1.42)$ conditions; $\mathrm{t}(42)=1.004, \mathrm{p}=0.321$;

- There is no a significant difference in respondents' rating in 'satisfaction for materials' of section $101(\mathrm{M}=3.61, \mathrm{SD}=1.095)$ and section $103(\mathrm{M}=3.91, \mathrm{SD}=1.095)$ conditions; $\mathrm{t}(42)=0.909, \mathrm{p}=0.369$;

- There is no a significant difference in respondents' rating in overall CES average of section $101(\mathrm{M}=3.48, \mathrm{SD}=1.19)$ and section $103(\mathrm{M}=3.83, \mathrm{SD}=1.19)$ conditions; $\mathrm{t}(42)=0.975, \mathrm{p}=0.334$; 
International Journal of Advanced Information Technology (IJAIT) Vol. 8, No.6, December 2018

Table 13. Group Statistics for Q18, Satisfaction, and Overall Average of CES

\begin{tabular}{llllll}
\hline & Section & $\mathbf{N}$ & Mean & $\begin{array}{l}\text { Std. } \\
\text { Deviation }\end{array}$ & $\begin{array}{l}\text { Std. Error } \\
\text { Mean }\end{array}$ \\
\hline Q18 & 101 & 22 & 3.25 & 0.76 & 0.229 \\
& 103 & 22 & 3.64 & 0.76 & 0.229 \\
\hline Satisfaction to & 101 & 22 & 3.6 & 1.42 & 0.428 \\
Instructor & 103 & 22 & 4.03 & 1.42 & 0.428 \\
\hline Satisfaction for Ma- & 101 & 22 & 3.61 & 1.095 & 0.330 \\
terials & 103 & 22 & 3.91 & 1.095 & 0.330 \\
\hline Overall CES & 101 & 22 & 3.48 & 1.19 & 0.359 \\
Average & 103 & 22 & 3.83 & 1.19 & 0.359 \\
\hline
\end{tabular}

Table 14. Independent Samples Test for Q18, Satisfaction, and Overall Average of CES

\begin{tabular}{|c|c|c|c|c|c|c|c|c|}
\hline & & $\mathbf{t}$ & df & $\begin{array}{l}\text { Sig. (2- } \\
\text { tailed) }\end{array}$ & $\begin{array}{c}\text { Mean } \\
\text { Difference }\end{array}$ & $\begin{array}{l}\text { Std. Error } \\
\text { Difference }\end{array}$ & $\begin{array}{l}95 \% \text { Con } \\
\text { Interval o } \\
\text { ference } \\
\text { Lower }\end{array}$ & $\begin{array}{l}\text { lence } \\
\text { the Dif- } \\
\text { Upper }\end{array}$ \\
\hline Q18 & $\begin{array}{l}\text { Equal va- } \\
\text { riances } \\
\text { assumed }\end{array}$ & 1.702 & 42 & 0.0962 & 0.390 & 0.229 & -0.0724 & 0.8524 \\
\hline $\begin{array}{l}\text { Satisfac- } \\
\text { tion for } \\
\text { Instructor }\end{array}$ & $\begin{array}{l}\text { Equal va- } \\
\text { riances } \\
\text { assumed }\end{array}$ & 1.004 & 42 & 0.3210 & 0.430 & 0.428 & -0.4340 & 1.2940 \\
\hline $\begin{array}{l}\text { Satisfac- } \\
\text { tion for } \\
\text { Materials }\end{array}$ & $\begin{array}{l}\text { Equal va- } \\
\text { riances } \\
\text { assumed }\end{array}$ & 0.909 & 42 & 0.3687 & 0.300 & 0.330 & -0.3663 & 0.9663 \\
\hline $\begin{array}{l}\text { Overall } \\
\text { CES } \\
\text { average }\end{array}$ & & 0.975 & 42 & 0.3349 & 0.350 & 0.359 & -0.3741 & 1.0741 \\
\hline
\end{tabular}

These results suggest respondents' viewpoints on traditional and blended learning method have no statistical differences. Therefore, it can be concluded that grading of assignments, satisfaction on the instructor's way of teaching, and materials using either traditional or blended doesn't affect the effectiveness of the teaching method. Effective learning still lies in the hand of the teacher.

\section{CONCLUSIONS AND RECOMMENDATIONS}

This research paper assessed the effectiveness of "traditional" and "blended learning" teaching method in the Business Communication course. Based on the findings, the following conclusions were drawn: 
International Journal of Advanced Information Technology (IJAIT) Vol. 8, No.6, December 2018

1. Students' performance in ENLG118 (English Composition) and year level have significant correlation with student's performance in BUS261, but cannot be the sole predictors of his performance in BUS261.

2. There was a difference in scores of assessments due to students' year level and performance in ENGL 118.

3. Based on the Course Evaluation Survey (CES), respondents signified a neutral viewpoint on 'traditional' and 'blended learning' pedagogical approach.

4. The teacher is still the greatest factor that affects the effectiveness of teaching.

5. It is further concluded, that if the controlled groups will compose of same characteristics, such as respondents' year level and all of them took the ENGL118 as a prerequisite for BUS261, blended learning pedagogical approach might be more effective than the traditional method.

Based on the conclusions drawn, the following recommendations are hereby offered:

1. Fully utilizing "Blackboard" not only in the BUS261 course but also to other courses as applicable, since Royal Commission invested on this technology to be in line with the socalled "4th Industrial Revolution" and prepare the students adept in technology.

2. Teachers, who are the primary facilitators of learning, should also be trained in using the "Blackboard" technology so that they can acquire the necessary skills and competencies needed for blended learning pedagogical approach.

3. A further study is recommended to determine the validity of this study or this study can also be adopted by other courses or educational institutions under the umbrella of the Royal Commission.

\section{REFERENCES}

[1] Alammary, A., Sheard, J., \& Carbone, A. (2014). Blended learning in higher education: Three different design approaches. Australasian Journal of Educational Technology, 30(4). https://ajet.org.au/index.php/AJET/article/view/693/1061

[2] Allen E., \& Seaman J. (2011). Going the Distance: Online educator in the United States. (Survey). Babson Survey Research Group.

[3] Aslam, S. (n.d.). A Comparative Study of Blended Learning versus Traditional Teaching in Middle School Science. International Conference: The Future of Education. https://conference.pixelonline.net/FOE/files/foe/ed0005/FP/1718-SOE1072-FP-FOE5.pdf

[4] Al-Azawei, A., Parslow P., \& Lundqvist K. (2017). Investigating the effect of learning styles in a blended e-learning system: An extension of the technology acceptance model (TAM). Australasian Journal of Educational Technology, 33(2). https://ajet.org.au/index.php/AJET/article/view/2741/1406

[5] BlackBoardLearn (n.d.) Retrieved on 20/2/2018 from http://www.blackboard.com/index.html

[6] Bliuc, A. G. (2007). Research focus and methodological choices in studies into. In Internet and Higher Education, 10, 31-244 
International Journal of Advanced Information Technology (IJAIT) Vol. 8, No.6, December 2018

[7] Crawford, R., Jenkins, L. (2017). Blended learning and team teaching: Adapting pedagogy in response to the changing digital tertiary environment. Australasian Journal of Educational Technology, 33(2). https://ajet.org.au/index.php/AJET/article/view/2924/1414

[8] Statistics How to (n.d). Retrieved from https://www.statisticshowto.datasciencecentral.com/probability-and-statistics/find-sample-size/

[9] Fadde, P. J., \& Phu Vu. (2014). Blended Online Learning: Benefits, Challenges, and Misconceptions. In P. Lowenthal, C. S. York, and J. C. Richardson (Eds.), Online Learning: Common Misconceptions, Benefits,and Challenges (pp. 33-48). New York: Nova.

[10] Fung, JL., Quek, CL. (2016). Modeling relationships between students' academic achievement and community of inquiry in an online learning environment for a blended course. Australasian Journal of Educational Technology, 32(4). https://ajet.org.au/index.php/AJET/article/view/2500/1375

[11] Graham, C. R. (2005). Blended learning systems: definition, current trends, and future definitions. In C. J. Bonk \& C. R. Graham (Eds.), Handbook of blended learning: Global perspectives, local design. (pp. 3 -21). San Francisco, CA: Pfeiffer Publishing.

[12] Heinrich, E. \& Milne, J. (2012). Pathways for improving support for the electronics management and marking of assignments. Australasian Journal of Educational Technology, 28(2), 279-294. https://ajet.org.au/index.php/AJET/article/view/874/152

[13] Heinrich, E., Milne, J. D. \& Moore, M. (2009). An investigation into e-tool use for formative assignment assessment - status and recommendations. Educational Technology \& Society, 12(4), 176192. http://www.ifets.info/journals/12_4/16.pdf

[14] Heinze, A., Procter, C. (2004). "Reflections on the Use of Blended Learning". Education in a Changing Environment. University of Salford, Salford, Education Development

[15] Jubail University College (2018). About Jubail University College. Retrieved on 20/2/2018 from http://www.ucj.edu.sa/en/about/Pages/About-Jubail-University-College.aspx

[16] Khan, A., et. al (2012). Study of Blended Learning Process in Education. I.J.Modern Education and Computer Science, 9, 23-29, DOI: 10.5815/ijmecs.2012.09.03

[17] Medina, L.C. (2018). Blended learning: Deficits and prospects in higher education. Australasian Journal of Educational Technology, 34(1). https://ajet.org.au/index.php/AJET/article/view/3100/1460

[18] Montgomery, A., Hayward, D., et. al (2015). Blending for student engagement: Lessons learned for MOOCs and beyond. Australasian Journal of Educational Technology, 31(6). https://ajet.org.au/index.php/AJET/article/view/1869/1321

[19] Murphy, R., et. al (2014). Blended Learning Report. Michael \& Susan Dell Foundation in Partnership with SRI International.

[20] Nazarenko, A. (2015). Blended Learning vs Traditional Learning: What Works? (A Case Study Research). The XXVI Annual International Academic Conference, Language,and Culture, 27-30, October 2015. Propecia - Social and Behavioral Science 200 (2015) 77-82. https:// https://www.sciencedirect.com/science/article/pii/S1877042815046662 
International Journal of Advanced Information Technology (IJAIT) Vol. 8, No.6, December 2018

[21] O'Flaherty, J., \& Phillips, C. (2015). The use of flipped classrooms in higher education: A scoping review. The Internet and Higher Education, 25, 85-95.

[22] Omiola, M., et. al (2012). Effects of Blended Learning and Individualized Instructional Strategies on the Cognitive Learning Outcomes in Basic Technology. British Journal of Science Vol. 6 (1) 38-44.

[23] Ryback, D., \& Sanders, J. (1980). Humanistic versus traditional teaching styles and student satisfaction. Journal of Humanistic Psychology, 20(87), 87-90

[24] Sarka, A., Semradova, I. (2016). Evaluation of Blended Learning. Future Academy's Multidisciplinary Conference.Propecia - Social and Behavioral Science 217 (2016) 551-557. https:// https://www.sciencedirect.com/science/article/pii/S1877042815046662

[25] Saunders, M., Lewis, P., Thornhill, A. (2012). Research Methods for Business Students. Pearson, UK.

[26] Shih, W., Tsai, C. (2017). Students' perception of the flipped classroom approach to facilitating online project-based learning in marketing research course. Australasian Journal of Educational Technology, 33(5). https://ajet.org.au/index.php/AJET/article/view/2884/1436

[27] Simon, D., Jackson, K., \& Maxwell, K. (2013). Traditional Versus Online Instruction: Faculty Resources Impact Strategies for Course Delivery. Business Education \& Accreditation. Vol. 5, November 1. ftp://ftp.repec.org/opt/ReDIF/RePEc/ibf/beaccr/bea-v5n1-2013/BEA-V5N1-2013-9.pdf.

[28] Staker, H. \& Horn, M. (2012). Classifying K-12 blended learning. Clayton Christensen Institute for Disruptive Innovation: San Mateo, CA

[29] Strauss, Valerie (3 June 2012). "The flip: Turning a classroom upside down". Washington Post.

[30] Talaue, G. (2017). Research Writing Handbook: A Guide for Basic Research. Scholar's Press. Germany.

[31] Tayfour, A., Siraj, M (2017), "Analysis of Factors Affecting Student Evaluation of Teaching Effectiveness in Saudi Higher Education: The Case of Jubail University College.” American Journal of Educational Research, vol. 5, no. 5 (2017): 464-475. doi: 10.12691/education-5-5-2.

\section{AUTHORS}

Fahad AlShahrani holdsa doctorate degree in Instructional Technology. He is currently the Director of the eLearning Center of Royal Commission of Jubail.

Gilbert M. Talaue holds doctorate degree in Business Administration. He is currently working at Jubail University College in Kingdom of Saudi Arabia as Assistant Professor of Business Administration.
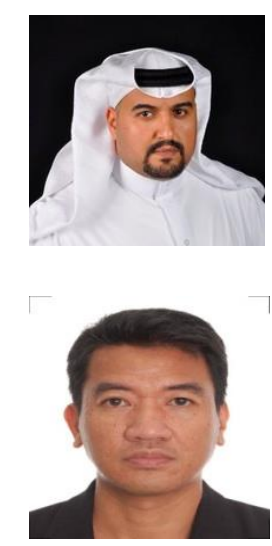